\title{
Neurological Complications Associated with the Blood-Brain Barrier Damage Induced by the Inflammatory Response During SARS-CoV-2 Infection
}

\author{
Iván Alquisiras-Burgos ${ }^{1}$ (D) - Irlanda Peralta-Arrieta ${ }^{2}$ (1) - Luis Antonio Alonso-Palomares ${ }^{3}$ (D) \\ Ana Elvira Zacapala-Gómez ${ }^{4}$ (D) • Eric Genaro Salmerón-Bárcenas ${ }^{5}$ (D) Penélope Aguilera ${ }^{1}$ (D)
}

Received: 19 August 2020 / Accepted: 16 September 2020 / Published online: 25 September 2020

(C) Springer Science+Business Media, LLC, part of Springer Nature 2020

\begin{abstract}
The main discussion above of the novel pathogenic severe acute respiratory syndrome coronavirus 2 (SARS-CoV-2) infection has focused substantially on the immediate risks and impact on the respiratory system; however, the effects induced to the central nervous system are currently unknown. Some authors have suggested that SARS-CoV-2 infection can dramatically affect brain function and exacerbate neurodegenerative diseases in patients, but the mechanisms have not been entirely described. In this review, we gather information from past and actual studies on coronaviruses that informed neurological dysfunction and brain damage. Then, we analyzed and described the possible mechanisms causative of brain injury after SARS-CoV-2 infection. We proposed that potential routes of SARS-CoV-2 neuro-invasion are determinant factors in the process. We considered that the hematogenous route of infection can directly affect the brain microvascular endothelium cells that integrate the blood-brain barrier and be fundamental in initiation of brain damage. Additionally, activation of the inflammatory response against the infection represents a critical step on injury induction of the brain tissue. Consequently, the virus' ability to infect brain cells and induce the inflammatory response can promote or increase the risk to acquire central nervous system diseases. Here, we contribute to the understanding of the neurological conditions found in patients with SARS-CoV-2 infection and its association with the blood-brain barrier integrity.
\end{abstract}

Keywords SARS-CoV-2 · COVID-19 - Blood-brain barrier · Neurological complications · Inflammatory response · Neurotropism

Penélope Aguilera

penelope.aguilera@innn.edu.mx

1 Laboratorio de Patología Vascular Cerebral, Instituto Nacional de Neurología y Neurocirugía "Manuel Velasco Suárez", Insurgentes Sur \#3877, 14269 Ciudad de México, Mexico

2 Laboratorio de Epigenómica del Cáncer y Enfermedades Pulmonares, Unidad de Investigación en Biomedicina, Facultad de Estudios Superiores-Iztacala, Universidad Nacional Autónoma de México, 54090 Tlanepantla, Estado de México, Mexico

3 Molecular and Cellular Virology Laboratory, Virology Program, Institute of Biomedical Sciences, Faculty of Medicine, Universidad de Chile, 8380453 Santiago, Chile

4 Laboratorio de Biomedicina Molecular, Facultad de Ciencias Químico Biológicas, Universidad Autónoma de Guerrero, 39070 Chilpancingo de los Bravo, Mexico

5 Departamento de Biomedicina Molecular, Centro de Investigación y de Estudios Avanzados del Instituto Politécnico Nacional, 07360 Ciudad de México, Mexico

\section{Coronaviruses}

Coronaviruses (CoVs) belong to the order Nidovirales and family Coronaviridae which is grouped on four genera based on phylogeny: Alphacoronavirus, Betacoronavirus, Gammacoronavirus, and Deltacoronavirus (International Committee for Taxonomy of Virus; https://talk.ictvonline. org/). CoVs are envelopment and spherical particles of 80 to $120 \mathrm{~nm}$ in diameter with a crown-like structures. This family contains the largest and non-segmented RNA genome, which is formed with a single-strand positive-sense around 27 to $32 \mathrm{~kb}$ in size [1]. CoVs' genome shares structural organization, although differs in the base pairs number and sequence, even among closely related CoVs. The open reading frames $1 \mathrm{a} / \mathrm{b}$ (ORF1a and ORF1b), located at the $5^{\prime}$ end encode nonstructural components, the polyproteins pp $1 \mathrm{a}$ and $\mathrm{pp} 1 \mathrm{~b}$. Two viral proteases cleave these proteins to generate 16 nonstructural proteins (nsp1 to nsp16), including the RNAdependent RNA polymerase (RdRP), an important protein 
involved in genome transcription and replication. The 3' end includes ORFs that encode four major structural proteins: the spike surface glycoprotein (S), a small envelope protein $(\mathrm{E})$, membrane protein $(\mathrm{M})$, and nucleocapsid protein $(\mathrm{N})$ that covers the RNA (Fig. 1). Besides, the CoV genome maintains genes that encode accessory proteins indispensable for adaptation and virulence and be successful to specific host $[2,3]$.

The Betacoronavirus are zoonotic pathogens that have a wild animal origin, for example, bat or rodent origin. This group includes pathogenic human $\mathrm{CoVs}(\mathrm{HCoVs})$, such as HCoV-229E, HCoV-OC43, HCoV-NL63, and HCoVHKU1, that infect mammals and provoke mild related respiratory illness in infants, young children, elderly individuals, and immunocompetent hosts [1,3]. However, the severe acute respiratory syndrome-related $\mathrm{CoV}$ (SARS-CoV) and the Middle East respiratory syndrome-related CoV (MERS$\mathrm{CoV}$ ) cause a severe respiratory syndrome in humans that aroused large-scale pandemics during 2002-2003 and 2012, respectively [4, 5]. Importantly, late in December 2019, Wuhan Municipal Health Commission, China, reported a cluster of cases of atypical pneumonia in Wuhan, Hubei Province, China, associated with a virus that rapidly spread all over the world.

\section{Severe Acute Respiratory Syndrome CoV-2 (SARS-CoV-2)}

Briefly, on December 26, 2019, a male patient of 41 years old, who worked at the local seafood market, was hospitalized in the Central Hospital of Wuhan. The patient-reported symptoms are fever, chest tightness, cough, pain, weakness, sputum production, and dyspnea [6]. For its origin, it was speculated that the disease could be associated with a CoV. This information was confirmed after the unknown virus was isolated from bronchial-alveolar lavage fluid from the patient [6]. On January 12,2020 , China publicly shared the genetic sequence of a new $\mathrm{CoV}$.
Metagenomic RNA sequencing identified a new RNA virus whose genome sequence of 29,903 nucleotides was designated as WH-Human1 coronavirus [6], later referred to as 2019 novel coronavirus, and at present named as SARS CoV type 2 (SARS-CoV-2) by the World Health Organization (WHO). SARS-CoV-2 has an overall genome sequence identity of $82 \%$ with SARS-CoV [7] and $96.2 \%$ with batCoV RaTG13 (Rhinolophus affinis) from Yunnan province, suggesting a bat origin [8]. Although the origin of SARS-CoV2 is zoonotic, there is no certainty of its intermediate animal host. Some studies indicated that snakes were the intermediate hosts, but the most recent research concluded that some pangolin species are the missing link [9-11].

On January 30, 2020, the WHO declared SARS-CoV-2 outbreak a Public Health Emergency of International Concern and pandemic on March 11, 2020. The global situation by SARS-CoV-2 infections reported to the WHO by August 15, 2020, includes 21,026,758 confirmed cases and 755,786 deaths, while the America region reported 11,271,215 confirmed cases (https://covid19.who.int/).

\section{Clinical Features of CoV Coronavirus Disease 2019 (COVID-19)}

Pathogenicity and transmission capacity of any pathogen are indicated from the $R_{0}$ value. Epidemiologically, $R_{0}$ is defined as the average number of people who will acquire a disease from an infected person. Therefore, $R_{0}$ indicates the potential spread (contagious) or decline of disease. When $R_{\mathrm{o}}<1$, the condition will decline and eventually disappear; if $R_{0}=1$, the disease will stay alive, but will not turn in to an epidemic; with values of $R_{\mathrm{o}}>1$, cases could grow exponentially and cause an epidemic or a pandemic [12]. The transmissibility and mortality rate of SARS-CoV-2 have been reported by several authors, and the estimated value is so far under debate (for more detail, see reference Liu et al. [12]). However, according to Chen et al. [13], it is estimated that SARS-CoV-2 has
Fig. 1 SARS-CoV-2 genome organization. The SARS-CoV-2 genome size is around $32 \mathrm{~kb}$ and is an RNA single-strand positivesense that encodes 16 nonstructural proteins ( $5^{\prime}$ end) and 4 structural proteins ( $3^{\prime}$ end) $(\mathrm{S}, \mathrm{E}$, $\mathrm{M}$, and $\mathrm{N}$ ) and 6 accessory proteins. SARS-CoV-2 genome. The genome contains a PoliA tail at $3^{\prime}$ end

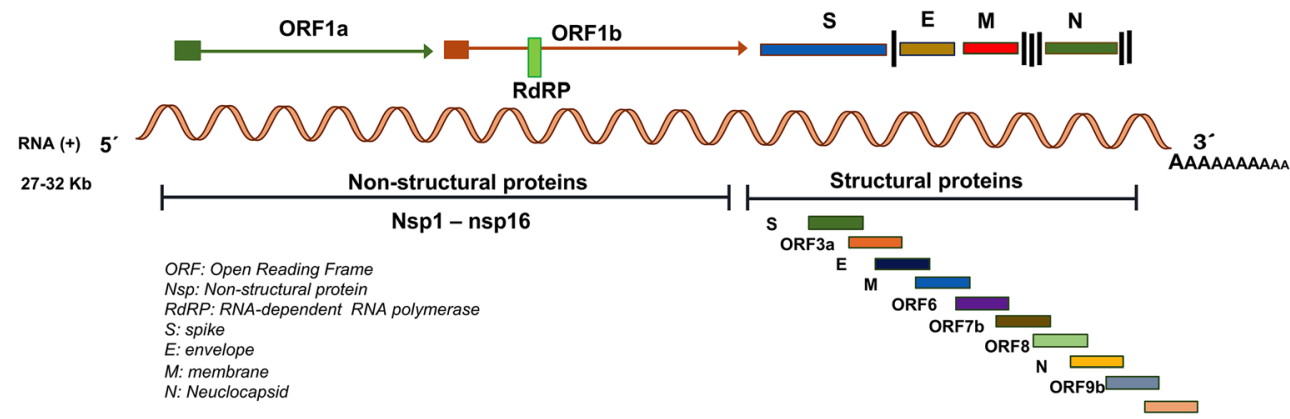

ORF14? 
relatively low pathogenicity ( $3 \%$ ) and moderate transmissibility $\left(R_{0}=1.4-5.5\right)$.

COVID-19 is the illness caused by SARS-CoV-2 infection. SARS-CoV-2 infects the higher upper respiratory tract, but with increased disease severity, the lower respiratory tract is also affected. The main routes of transmission are respiratory droplets and human-to-human, close contact $[7,14,15]$. However, oral-fecal transmission, tears secretion, aerosols, fomites, and even air and surface environmental (e.g., patient's room, floor, air outlet fan, toilet area, and personal protective equipment) are other possible routes of virus' transmission; nevertheless, the effectiveness of these alternative routes is still controversial [15-18]. SARS-CoV-2 infection is possible for the entire population; however, the severity of the illness depends on some highlighted aspects seen around the world. In this sense, higher percentages of infection have been diagnosed in men than in women [19-21], and elderly males $(\geq$ 80 years) are the group more susceptible to complications [22]. Besides, chronic underlying diseases, such as hypertension, diabetes, coronary heart disease, and cancer, have a meaningful impact in case fatality risk $[22,23]$. On the other hand, pediatric patients ( 2 months to 17 years) may have mild symptoms or be asymptomatic; in fact, they have their own clinical features [24-27].

The period of incubation of the SARS-CoV-2, which determines the time in which symptoms are observed, has a wide range from 1 to 14 days [14, 20, 28]. Early and common symptoms by COVID-19 include fever, dry cough, shortness of breath, and chest pain; other symptoms include myalgia, fatigue, and headache. Less common symptoms are sputum production, hemoptysis, and gastrointestinal symptoms, including diarrhea, nausea, and vomiting [22, 28-31]. Depending on illness evolution, COVID-19 might be classified according to the severity of the clinical symptoms in mild (i.e., non-pneumonia and development mild pneumonia); severe (i.e., dyspnea, respiratory frequency $\geq 30$ breaths per minute, blood oxygen saturation $\leq 93 \%$, the partial pressure of arterial oxygen to fraction of inspired oxygen ratio $<300$, and lung infiltrates $>50 \%$ in the first 24 to $48 \mathrm{~h}$ ); and critical (i.e., respiratory failure, sepsis, septic shock, acute respiratory distress syndrome, and/or multiple organ dysfunction or failure, for example, heat failure, coagulopathy, acute cardiac, and acute kidney injury) $[22,23,31]$.

Clinical diagnosis is made based on symptoms, exposure, and chest imaging that show the presence of lung imaging features consistent with CoVs pneumonia that includes ground-glass lung $[32,33]$. The respiratory tract is the classical target for SARS-CoV-2 infection; nonetheless, the virus is also visualized by immunofluorescent staining in gastric, duodenal, and rectum glandular epithelial cells [18], showing other target tissues and complexity of the illness. Interestingly, there is evidence of signs and symptoms of
COVID-19 patients (Table 1) and other HCoVs infections [38].

\section{Neurotropism of SARS-CoV-2}

Up to date, many reports have described the association between respiratory viral infections with neurological symptoms. There are several recognized respiratory pathogens that gain access to the central nervous system (CNS), for instance, respiratory syncytial virus, the influenza virus, the human metapneumovirus, and HCoVs (HCoV229E, HCoV-OC43, and SARS-CoV) [39], that induce manifestations such as febrile or afebrile seizures, among other encephalopathies [ 40 , 41].

Primary cultures of human astrocytes and microglia and various human neuronal cell lines, such as the neuroblastoma SK-N-SH, the neuroglioma H4, and the oligodendrocytic MO3.13, have potential tropism for HCoV-OC43 [42]. Using an experimental animal model, HCoV-OC-43 infection also showed neuro-invasiveness and neuro-virulence [43]. Therefore, it is not surprising to find brain SARS-positive autopsies. Using in situ hybridization, the SARS genomic sequence has been detected in the cytoplasm of neurons of the hypothalamus and cerebral cortex [44]. Furthermore, Moriguchi et al. [45] confirmed the presence of the new SARS-CoV-2 in cerebral spinal fluid. In accord, epidemiological and clinical research have described neurological, noncommon symptoms, and neurological manifestations associated with the SARS-CoV-2 infection (Table 2). These clinical features include neuralgia, confusion, hyposmia, hypogeusia, and altered consciousness, symptoms that evidence the neurotropic invasion by SARS-CoV-2 [19, 41].

Despite the evidence demonstrating the neurotropism of respiratory viruses, the exact mechanism of neuro-invasion accomplished by viruses remains currently unknown. However, the route of invasion of the CNS has recently been described for HCoV-OC-43. This virus gains access to the CNS through the olfactory bulb, moving along the olfactory nerve. Then, neuro-propagation occurs along the multiple axonal connections expanding through the CNS (e.g., neuron-toneuron propagation or diffusing particles) [56]. Similar to $\mathrm{HCoV}-\mathrm{OC}-43$, a model in vivo of SARS-CoV infection suggested that the virus enters the brain via the olfactory bulb, and then, a transneuronal spread could occurs [57].

Also, some infectious blood-borne viruses primarily targeting peripheral organs have evolved strategies to thwart the blood-brain barrier (BBB). These strategies include direct infection of the brain microvascular endothelial cells that form the BBB, a paracellular entry that involves alteration of the tight junctions, or the "Trojan horse" invasion, via the traffic of infected monocytes/macrophages migrating across the $\mathrm{BBB}$, in a similar manner as the not-respiratory 
Table 1 Signs of neurological associated with SARS-CoV-2 infection

\begin{tabular}{|c|c|c|}
\hline Type of study & Signs and symptoms/cases $(\%)$ & Reference \\
\hline $\begin{array}{l}\text { Retrospective, single-center case series } \\
n=138 \text { patients }\end{array}$ & $\begin{array}{l}\text { Dizziness } \\
13(9.4 \%) \\
\text { Headache } \\
9(6.5 \%)\end{array}$ & {$[21]$} \\
\hline $\begin{array}{l}\text { Retrospective } \\
n=38 \text { patients }\end{array}$ & $\begin{array}{l}\text { Headache } \\
3(8 \%)\end{array}$ & {$[30]$} \\
\hline $\begin{array}{l}\text { Retrospective, single-center study } \\
n=99 \text { patients }\end{array}$ & $\begin{array}{l}\text { Confusion } \\
9(9 \%) \\
\text { Headache } \\
8(8 \%)\end{array}$ & [19] \\
\hline $\begin{array}{l}\text { Retrospective, observational case series } \\
n=214 \text { patients }\end{array}$ & $\begin{array}{l}\text { Neurological manifestations } \\
78(36.4 \%) \\
\text { Central nervous system (CNS) manifestations } \\
53(24.8 \%) \\
\text { Dizziness } \\
36(16.8 \%) \\
\text { Headache } \\
28(13.1 \%) \\
\text { Others symptoms: impaired consciousness, acute cerebrovascular disease, ataxia, seizure } \\
\text { Peripheral nervous system (PNS) manifestations } \\
19(8.9 \%) \\
\text { Taste impairment } \\
12(5.6 \%) \\
\text { Smell impairment } \\
11(5.1 \%) \\
\text { Others symptoms: vision impairment, nerve pain }\end{array}$ & {$[34]$} \\
\hline $\begin{array}{l}\text { Case report } \\
n=1 \text { patient }\end{array}$ & Anosmia & [35] \\
\hline $\begin{array}{l}\text { Retrospective observational study } \\
n=114 \text { patient }\end{array}$ & $\begin{array}{l}\text { Anosmia associated with dysgeusia } \\
54(47 \%)\end{array}$ & {$[36]$} \\
\hline $\begin{array}{l}\text { Retrospective report } \\
n=24 \text { males } \\
n=19 \text { females }\end{array}$ & $\begin{array}{l}\text { CNS syndromes } \\
\text { Encephalopathies } \\
10(23 \%) \\
\text { Symptoms: confusion and disorientation, psychosis, and seizures } \\
\text { Neuroinflammatory syndromes } \\
12(27 \%) \\
\text { Symptoms: encephalitis, features of an autoimmune encephalitis stimulus sensitive myoclonus, } \\
\quad \text { and convergence spasm. Confusion and seizure. } \\
\text { Acute demyelinating encephalomyelitis (ADEM): } 9(21 \%) \\
\text { Hemorrhagic } \\
5(12 \%) \\
\text { Necrotizing encephalitis } \\
1(2 \%) \text {, } \\
\text { Myelitis } \\
2(5 \%) \\
\text { Hemorrhagic leucoencephalitis } \\
1(2 \%)\end{array}$ & {$[37]$} \\
\hline
\end{tabular}

immunodeficiency virus 1 (HIV-1) [58, 59]. Likewise, when human primary monocytes are activated following infection by $\mathrm{HCoV}-229 \mathrm{E}$ and eventually become macrophages, it can invade tissues, including the CNS [60, 61]. Additionally, it has been reported that through activation of the brain microendothelium, the damage caused by the inflammatory response, allows the virus to reach the CNS. In this sense, the neuro-invasion of SARS-CoV-2 could occur through trans-synaptic transfer, via the olfactory nerve, infection of vascular endothelium, or leukocyte migration across the BBB [38].

\section{The SARS-CoV-2 Receptor}

The cellular tropism of $\mathrm{CoV}$ depends on the location of its receptor which can be expressed in cells different from those of the respiratory system. Therefore, if SARS-CoV-2 has 
Table 2 Neurological manifestations associated with SARS-CoV-2 infection

\begin{tabular}{|c|c|c|}
\hline Type of study and data of patients & Neurological diagnostic, symptoms, and clinical specimen for SARS-CoV-2 detection & Reference \\
\hline $\begin{array}{l}\text { Case series } \\
n=4 \text { patients } \\
73 \text { Y/A male, } 83 \text { Y/A female, } 80 \text { Y/A female, and } 88 \\
\quad \text { Y/A female }\end{array}$ & $\begin{array}{l}\text { Acute stroke } \\
\text { Altered mental status, facial droop, slurred speech, left-side weakness, hemiplegia, } \\
\text { and aphasia } \\
\text { Not specific specimen }\end{array}$ & [46] \\
\hline $\begin{array}{l}\text { Case report } \\
n=2 \text { patients } \\
31 \text { Y/A male, } 62 \text { Y/A female }\end{array}$ & $\begin{array}{l}\text { Hunt and Hess grade } 3 \text { subarachnoid hemorrhage from a rupture aneurysm } \\
\text { Headache and loss of consciousness } \\
\text { Ischemic stroke } \\
\text { Nasal specimen }\end{array}$ & [47] \\
\hline $\begin{array}{l}\text { Case report } \\
n=5 \text { patients } \\
<50 \mathrm{Y} / \mathrm{A}\end{array}$ & $\begin{array}{l}\text { Large-vessel stroke } \\
\text { Headache, dysarthria, numbness, hemiplegia, and reduced level of consciousness } \\
\text { Not specific specimen }\end{array}$ & {$[48]$} \\
\hline $\begin{array}{l}\text { Case report } \\
n=1 \text { patient } \\
41 \text { Y/A }\end{array}$ & $\begin{array}{l}\text { Meningoencephalitis } \\
\text { Seizure, lethargic, photophobia, worsening encephalopathy, disorientation, } \\
\text { hallucinations, and neck stiffness } \\
\text { Not specified specimen }\end{array}$ & {$[49]$} \\
\hline $\begin{array}{l}\text { Case report } \\
n=1 \text { patient } \\
24 \mathrm{Y} / \mathrm{A}\end{array}$ & $\begin{array}{l}\text { Meningitis/encephalitis } \\
\text { fatigue and fever, vomit, seizures, unconsciousness, and neck stiffness } \\
\text { Cerebral spinal fluid specimen }\end{array}$ & [45] \\
\hline $\begin{array}{l}\text { Retrospectively report } n=24 \text { males and } 19 \text { females } \\
16-85 \text { Y/A }\end{array}$ & $\begin{array}{l}\text { Stroke and stroke with pulmonary thromboembolism } \\
\text { Guillain-Barré syndrome } \\
\text { Nasopharyngeal specimen }\end{array}$ & {$[37]$} \\
\hline $\begin{array}{l}\text { Case report } \\
n=2 \text { patients } \\
52 \text { Y/A male, } 39 \text { Y/A male }\end{array}$ & $\begin{array}{l}\text { Variants of Guillain-Barré syndrome } \\
\text { Miller Fisher syndrome } \\
\text { Diplopia, gait instability, headache, anosmia, and ageusia } \\
\text { Polyneuritis cranialis and ageusia } \\
\text { Oropharyngeal specimen }\end{array}$ & {$[50]$} \\
\hline $\begin{array}{l}\text { Case report } \\
n=1 \text { patient } \\
61 \text { Y/A female }\end{array}$ & $\begin{array}{l}\text { Acute Guillain-Barré syndrome } \\
\text { Legs weakness and severe fatigue } \\
\text { Oropharyngeal specimen }\end{array}$ & {$[51]$} \\
\hline $\begin{array}{l}\text { Case report } \\
n=1 \text { patient } \\
65 \text { Y/A male }\end{array}$ & $\begin{array}{l}\text { Guillain-Barré syndrome } \\
\text { Acute progressive symmetric ascending quadriparesis, facial paresis bilaterally } \\
\text { Oropharyngeal specimen }\end{array}$ & {$[52]$} \\
\hline $\begin{array}{l}\text { Case report } \\
n=5 \text { patients }\end{array}$ & $\begin{array}{l}\text { Guillain-Barré syndrome } \\
\text { Nasopharyngeal specimen }\end{array}$ & {$[53]$} \\
\hline $\begin{array}{l}\text { Case report } \\
n=1 \text { patient }\end{array}$ & $\begin{array}{l}\text { Guillain-Barré syndrome } \\
\text { Nasopharyngeal specimen }\end{array}$ & {$[54]$} \\
\hline $\begin{array}{l}\text { Case report } \\
n=1 \text { patient } \\
58 \text { Y/A female }\end{array}$ & $\begin{array}{l}\text { Acute hemorrhagic necrotizing encephalopathy } \\
\text { Altered mental status } \\
\text { Nasopharyngeal specimen }\end{array}$ & {$[55]$} \\
\hline
\end{tabular}

reached the CNS, the infection of brain cells depends on receptor recognition. It is the first step of viral infection and a key determinant of the host cell and tissue tropism. Walls et al. [62] reported that the angiotensin-converting enzyme 2 (ACE2), a metallopeptidase, mediates SARS-CoV-2 entry into cells, establishing it as a functional receptor for this recently appeared CoV. Previous studies achieved with SARS-CoV also showed that the binding affinity between viruses and human ACE2 correlates with increased virus transmissibility and disease severity in humans [63].

The human ACE2 protein is included within the renin angiotensin system (RAS) which is widely known for its physiological roles in electrolyte homeostasis, body fluid volume regulation, and cardiovascular control in the peripheral circulation. Renin, an enzyme produced from the kidney, acts on angiotensinogen (AGT), a liver precursor, to release angiotensin I (Ang I), an inactive decapeptide. Human ACE2 cleaves Ang I to convert it to the active octapeptide Ang II, the effector peptide of RAS, which is essential for various physiological functions [64].

The RAS has been described in various tissues such as the heart, the kidney, the lungs, the liver, the retina, and the brain $[64,65]$. Chen et al. [66] screened the human ACE2 mRNA expression in human organs based on hGTEx database. They found that the digestive tract intestine displayed the highest expression of human ACE2, followed by the testis and the kidney. Consequently, the high vulnerability to SARS-CoV2 to these organs could explain the positive detection of the virus in the patient's feces and urine [67]. The expression of human ACE2 in the heart is lower than that in the intestine and 
kidney but higher than that in the lung, which serves as the main target organ for SARS-CoV-2, indicating a potential infection susceptibility of the human heart.

Unfortunately, there is relatively little information available on both the expression and regulation of RAS in the brain $[68,69]$. Dzau et al. [70] demonstrated the expression of the ACE2 mRNA in mouse and rat brains using Northern blot analyses, although low levels of the human ACE2 mRNA were shown in the human brain using quantitative real-time RT-PCR [71, 72]. Chappell et al. [73] made the first demonstration of the endogenous presence of the ACE2 protein in brain tissues of rats using reverse-phase high-performance liquid chromatography and radioimmunoassays. Later, immunohistochemistry studies showed that human ACE2 protein was restricted to endothelial and arterial smooth muscle cells of cerebral vessels [74]. However, Lavoie et al. [68] produced double-transgenic mice which express the green fluorescent protein driven by the renin promoter and the $\beta$-galactosidase driven by the human angiotensin gene promoter and found that both proteins are co-expressed in the medulla, the pons, the amygdala, the hypothalamus, and the hippocampus; additionally, other regions only expressed the ACE2 protein. Interestingly, ACE2 protein is predominant but not exclusive of neurons; astrocytes and glial cells also express it $[68,75$, 76]. Additionally, it is possible that the brain endothelium expresses the ACE2 protein since recent studies demonstrated the susceptibility to the infection of endothelial cells in other tissues $[66,77]$.

The virus surface-anchored spike protein (S) mediates the SARS-CoV-2 entry to the target cell. Protein S contains a receptor-binging domain (RBD) that specifically recognizes the ACE2. The RBD shows a hidden position in SARS$\mathrm{CoV}-2$ that lead to poor recognition of the host receptor; however, this problem is overcome with an ACE2 high binding affinity and a furin motif that allows its spike to be pre-activated. Therefore, pro-protein convertase furin $(\mathrm{PCF})$ plays an essential role in virus' membrane fusion $[78,79]$. $\mathrm{PCF}$ is a ubiquitously expressed subtilisin-related serine protease and member of the pro-protein convertase family that functions within the secretory and endocytic pathways and at the cell surface, cleaving pro-proteins. PCF has several substrates that include growth factors, receptors, coagulation proteins, plasma proteins, extracellular matrix components, and protease precursors (e.g., matrix metalloproteases). PCF activity contributes to numerous functions in CNS and also is involved in chronic pathological conditions [80]. PCF cleavage of viral envelope glycoproteins is necessary for the propagation of many lipid-enveloped viral pathogens. Accordingly, sequence alignment indicates that the PCF cleavage site in S protein is essential in CoV evolution [81]. Notably, the PCF cleavage site is involved in pathogenicity and modulates neuro-virulence. Some mutations in PCF induce severe encephalitis and break the BBB [82], while others lead to reduced neurotropism and limited dissemination within the CNS [83]. Therefore, evidence supports that SARS-CoV-2 can reach $\mathrm{SNC}$ and infect brain cells through $\mathrm{S}$ protein binding to ACE2 and modification by PCF.

\section{SARS-CoV-2 and the Function of the BBB}

The microvascular endothelial cells that form the BBB protect the CNS from a wide variety of toxins and microorganisms found in the blood. These cells express tight junction proteins that limit the movement between adjacent cells and are through specific transporters and receptor proteins that control entry and exit of molecules coming from the blood toward the brain parenchyma [84]. Therefore, the study of the damage induced to microvascular endothelial cells represents the central framework for understanding the molecular mechanisms of virus infection in the CNS $[85,86]$.

Disruption of the BBB occurs upon infection with several recognized neurotropic viruses. Arbovirus that belongs to the Flaviviridae family, such as the West Nile Virus and the Zika virus, can induce damage in the BBB caused by the host cell's response to viral factors. Experiments carried out using in vitro and in vivo models of the BBB have demonstrated that these viruses replicate in the brain microvascular endothelial cells and induce down-regulation and degradation of tight junction proteins leading to disruption of the BBB [87-90]. Similarly, Bleau et al. [91] evaluated the ability of $\mathrm{CoV}$ to enter the CNS, using the highly hepatotropic mouse hepatitis virus type 3 and the weakly hepatotropic mouse hepatitis type A59. The type 3-infected mice showed brain invasion that correlated with enhanced BBB permeability. The effect was associated with decreased expression of the zona occludens protein 1, the VE-cadherin, and the occludin. Since $\mathrm{CoV}$ are molecularly related in its mode of replication, it is speculated that other types of $\mathrm{CoV}$ use a similar mechanism of action to infect the brain microvascular endothelial cells [92, 93]. Importantly, it has been identified the presence of SARSCoV-2 in the brain microvascular endothelial cells in frontal lobe tissue obtained at postmortem examination from a patient with COVID-19 [94]. Besides, viral particles and viral genome sequences of SARS-CoV have been detected in the cytoplasm of neurons of the brain, mainly in the hypothalamus and the cortex $[44,95]$. This evidence suggests that SARS$\mathrm{CoV}-2$ crosses the BBB as well as others $\mathrm{HCoV}$.

Therefore, infection by several respiratory viruses, including SARS-CoV-2, affects the integrity of the BBB through different mechanisms. The virus causes direct cell stress, associated with most of the cytotoxic effects that lead to degeneration of infected cells, for example, SARS-CoV induces apoptosis [96]. Endothelial cells activation as part of the inflammatory response causes an increase in the expression of proteases, such as matrix metalloproteinase, that promotes the 
degradation of the tight junction proteins [97]. However, it is probable that the inflammatory response plays the most important role in the induction of the damage to BBB.

\section{The Inflammatory Response}

The regular activity of neuroinflammation is mainly to restore the homeostasis in the brain [98]. However, prolonged CNS inflammation and systemic inflammatory response as a result of a wide variety of pathologies such as viral infections may influence the BBB integrity and further outcome in neurological disorders $[99,100]$. Therefore, SARS-CoV-2 could cause damage to the BBB through the activation of the inflammatory immune response associated with a dysregulation around this process [101].

Activation of the microvascular endothelial cells has been associated with changes in BBB permeability. For example, during physiological conditions, immune cell migration into the CNS is rigorously controlled by mechanisms that operate at the level of the BBB. Notably, migration of circulating immune cells into the CNS is low and restricted to specific innate and adaptative immune cell subsets, such as lymphocytes, macrophages, and antigen presenting cells as dendritic cells that maintain immune surveillance in the CNS [102]. However, during viral infections, the migration of immune cells is increased. This is supported by histopathologic examination of the brain tissue in patients with SARS-CoV, where pathological infiltration of $\mathrm{CD} 68^{+}$monocytes/macrophages and $\mathrm{CD}^{+} \mathrm{T}$ lymphocytes has been found in the brain mesenchyme [95]. Similarly, the infiltration process, related to interactions between the $\beta 1$ and $\beta 2$ integrins expressed on leukocytes and their ligands [i.e., intercellular adhesion molecules (ICAM): ICAM-1, ICAM-2, and vascular cell adhesion molecule-1 (VCAM-1)] present on the surface of the microendothelial cells, that induce extravasation across the BBB under inflammatory conditions has been reported [103-107]. Evidence suggests that infection and activation of the microvascular endothelial cells by typical neurotrophic viruses increased endothelial adhesion molecules expression [88]. This condition facilitates the trafficking of virusesinfected immune cells into the CNS via the 'Trojan horse' mechanism [88].

Likewise, during viral replication in the host cells, the damage is caused because SARS-CoV-2 is a cytopathic virus that induces the release of damage-associated molecular patterns (DAMPs) [108]. DAMPs are endogenous molecules released from damaged cells that interact with molecules called pattern-recognition receptor (PRR) that induce in the neighboring epithelial cells, endothelial cells, and macrophages a state of high inflammation [109].

Once the virus interacts with the host cells, the viral genome and viral proteins can also be recognized by PRRs and activated the immune response. Different PRRs recognize SARS-CoV-2, for example, the Toll-like receptors (TLR), which are molecules expressed in many cell lines, including endothelial cells, macrophages, and dendritic cells. TLR3, TLR7, TLR8, and TLR9 induce several pathways of activation that produce proinflammatory cytokines and other antiviral molecules to control the infection. However, this response can be dysregulated and exacerbated cytokines production [110]. Also, NOD-like receptor (NLR), other PRR, activates the inflammasome complex and induces the activation state in some cell types such as macrophages and epithelial and even in the microvascular endothelial cells leading to high production of interleukin (IL)-1 $\beta$ and IL-18. Nevertheless, this mechanism needs to be studied in detail for the new $\mathrm{CoV}$ [111].

On the other hand, the viral RNA activates typical molecules such as the retinoic acid inducible gene 1 and the melanoma differentiation associated gene 5 and induces an antiviral state, in which interferons (IFN) are secreted (mainly IFN type I and III). Interferons are molecules important to clearance the viral infection to prevent viruses from replicating $[112,113]$. In patients with COVID-19, high levels of IFN, especially IFN I, are detected; this molecule blocks the viral replication in adjacent cells and produces some effects against the viral infection such as the induction of interferonstimulated gene expression, the stimulation of cytokines production, and the activation of immune response cells (i.e., macrophages, monocytes, and neutrophils) $[112,114]$. Other $\mathrm{CoV}$ infections have a similar response $[115,116]$.

Furthermore, patients infected with SARS-CoV-2 have increased levels of several cytokines and chemokines: TNF- $\alpha$, IFN- $\gamma$, interleukin-1 receptor antagonist (IL-1RA), IL-2, IL-6, IL-7, IL-8, IL-9, IL-10, and the granulocyte macrophage colony-stimulating factor; importantly, high levels of IL-6 have been linked to a worse prognosis in COVID-19 patients $[116,117]$. This high production and misbalance of all these molecules is defined as cytokines storm (CS), which could be an essential factor to cause disruption of the BBB [110]. Interestingly, CS induces the activation of platelets, neutrophils, monocytes, and macrophages; additionally, some of these molecules can interact with the complement and the coagulation systems and contribute to the pathogenic inflammation [117].

Furthermore, some chemokines can attract some innate immune response cells such as monocytes, natural killer cells, dendritic cells, and T cells [118] and induce the production others cytokines such as the monocyte chemotactic protein-1, the granulocyte colony-stimulating factor, the macrophages inflammatory protein $1-\alpha$, and IL-10 that recruit lymphocytes and monocytes and initiate the humoral response. Together, all these mechanisms can contribute to the severity of neurological symptoms of SARS-CoV-2 infection in the BBB [30]. 
Other physiological disturbances in COVID-19 patients such as thrombocytopenia, lymphopenia $\left(\mathrm{CD}^{+} \mathrm{T}, \mathrm{CD} 4^{+} \mathrm{T}\right.$, Treg cells, and platelets), and eosinopenia have also been describing. Blood samples and spleen and lymph nodes present these types of dysregulation due to the recruited cells to the infected sites to control the viral replication (Table 3) [119, 120]. Also, several patients present high levels of D-dimer in the early stage of the infection (Table 3). This molecule is an important marker in the disorder of coagulation. It represents a thrombotic state that leads to embolic vascular events and can produce venous clots and induce brain damage [121]. Therefore, COVID19 patients with high inflammation trigger excessive thrombin production that inhibits fibrinolysis and activates the complement pathways leading thromboinflammation, microthrombin deposition, and microvascular dysfunction associated with damage of the BBB [122, 123].

An unexplored mechanism that could produce damage in the $\mathrm{BBB}$ is the adaptative immune response. The generation of antibodies (Abs) against SARS-CoV-2 can cross-react with some molecules of the brain microvascular endothelial cells and produce damage through the activation of the complement system (C3 and $\mathrm{C} 4$ proteins). Also, Ab-dependent enhancement phenomenon can increase the infection and contribute to the injury. This process has been extensively studied in Dengue and Zika virus infection, where the Abs produced in the first exposure can cross-react in a second exposure and enhance the infection instead of neutralizing it [124, 125]. Additionally, the Abs can generate an autoimmune attack and interact with the virus forming immune complexes and induce the complement system activation [126].

Recently, some studies showed that the cellular immune response could be central to determine the disease condition.
Several viruses, including SARS-CoV-2, can activate CD4 ${ }^{+}$ and $\mathrm{CD}^{+}$and induce clonal expansion, specific cell effectors, and cellular memory $[127,128]$. Also, T cells can cross-react inducing a state of protection observed in unexposed people with SARS-CoV-2 [129, 130]. Finally, more studies around the interaction with SARS-CoV-2 and the host immune system need to be clarified. Research around the mechanisms involved in inflammation response can allow the development of strategies that might help to mitigate the health consequence of this pandemic.

\section{Neurological Implications of BBB Disruption by SARS-CoV-2}

As previously discussed, multiple respiratory viruses can affect the CNS. For example, the mouse hepatitis virus induces inflammation, BBB damage, and demyelination in rat models [131]. Likewise, a case report of HCoV-OC43 detected in nasopharyngeal and cerebral spinal fluid samples from a child patient exhibited acute disseminated encephalomyelitis, a low-prevalence CNS disease that induces demyelination [132]. The H1N1 virus, the causative agent of high mortality rates, also presented neurological complications. A retrospective study of the clinical files of 55 patients infected with H1N1 detected $50 \%$ of visible neurological symptoms [133]. Interestingly, most patients with neurological manifestations due to H1N1 infection manifested brain edema [134]. Importantly, in autopsy studies, patients with SARS-CoV showed endothelial activation associated with the loss of cerebral vascular integrity displaying multifocal hemorrhage [135]. Histological examination of brain tissue specimens of patients with SARS-CoV infection also showed neuronal

Table 3 Laboratory findings in neurological manifestation in COVID-19

\begin{tabular}{|c|c|c|c|}
\hline Author & Manifestation & Laboratory finding & Reference \\
\hline Avula et al. & Stroke & $\begin{array}{l}\text { - Lymphopenia } \\
\text { - Elevated C-reactive [26 mg/dl }(0.04 \mathrm{mg} / \mathrm{dl})] \\
\text { - Elevated D-dimer [mean } 8704 \mathrm{ng} / \mathrm{ml}(<880 \mathrm{ng} / \mathrm{ml}) \\
\text { - Elevated lactate dehydrogenase }(712 \mathrm{U} / \mathrm{L})\end{array}$ & {$[46,48]$} \\
\hline Oxley et al. & & - D-dimer $[5972 \mathrm{ng} / \mathrm{ml}(0-500 \mathrm{ng} / \mathrm{ml})]$ & \\
\hline Moringuchi et al. & Meningoencephalitis & $\begin{array}{l}\text { - Elevated neutrophil } \\
\text { - Increased C-reactive protein }\end{array}$ & {$[45]$} \\
\hline Guitierrez-Ortiz et al. & $\begin{array}{l}\text { Guillain-Barré } \\
\text { syndrome }\end{array}$ & $\begin{array}{l}\text { - Lymphopenia }(1000 \text { cells } / \mu \mathrm{l}) \\
\text { - Leucopenia }(3100 / \text { cells } / \mu \mathrm{l}) \\
\text { - Elevated C-reactive protein }(2.8 \mathrm{mg} / \mathrm{dl}) \\
\text { - Positive GD1b-IgG ganglioside antibody }\end{array}$ & {$[50,51,54]$} \\
\hline $\begin{array}{l}\text { Virani et al. } \\
\text { Zhao et al. }\end{array}$ & & $\begin{array}{l}\text { - Lymphopenia and thrombocytopenia } \\
\text { - Lymphocytopenia }\left[0.52 \times 10^{9} / \mathrm{L}\left(1.1-3.2 \times 10^{9} / \mathrm{L}\right)\right] \\
\text { - Thrombocytopenia }\left[113 \times 10^{9} / \mathrm{L}\left(125-3000 \times 10^{9} / \mathrm{L}\right)\right]\end{array}$ & \\
\hline
\end{tabular}


degeneration, necrosis, edema, extensive glial cell hyperplasia, and cellular infiltration of the vascular walls by monocytes and lymphocytes [40].

With this background, several studies have attempted to characterize the neurological manifestations of SARS$\mathrm{CoV}-2$. An increasing number of individual case reports have emerged describing acute neurological disorders ranging from Guillain-Barré syndrome and acute myelitis to acute hemorrhagic necrotizing encephalopathy [136]. Although the long-term neurological implications of SARS-CoV-2 infection are still unknown, important clues suggest that complications of the disease are related to CNS invasion by damaging the BBB.

\section{Neurological Implications of BBB Disruption by SARS-CoV-2 in Long-Term Dementia}

There is a very complex interaction between the brain cells and the cerebral vasculature. Consequently, preservation of the cerebrovascular function and its integrity has a central role in this sophisticated communication. Additionally, any derangements can have deleterious acute and chronic consequences such as the development of neurodegenerative diseases and dementia [137].

Infectious agents have been suspected as contributing factors to dementia, especially in Alzheimer's disease (AD). Interestingly, the BBB disruption appears to be an early feature of this disease [138]. For instance, Bell et al. [139] demonstrated that BBB breakdown was derived in neurotoxic proteins infiltration (e.g., amyloid- $\beta$ peptides, the hallmark of $\mathrm{AD})$, affecting neurons and either initiating or exacerbating neurodegeneration. Also, Ueno et al. [140] using experimental animal models exhibiting some phenotypes of vascular dementia showed that BBB damage might be related to amyloid- $\beta$ peptides accumulation. Accordingly, damage induced to the BBB by infectious agents might trigger neurodegenerative diseases in predisposed patients [141]. Therefore, viral infections such as SARS-CoV-2 could be associated with an increased risk of $\mathrm{AD}$ development and a faster rate of cognitive decline in older populations.

$\mathrm{AD}$ in systemic virus infection is an example of a condition that is primarily neurodegenerative; however, in many cases, it is not clear whether BBB changes are the cause or the effect of a neuropathology. Furthermore, it is possible that the BBB anomalies and the disease drive each other in a selfperpetuating manner, contributing to damage progression [142]. As mentioned, acute and chronic systemic inflammation accelerates the progress of AD [143]. Also, a 5-year follow-up study showed that viral infections, like the induced by cytomegalovirus, are linked with faster cognitive decline and development of AD [144]. Furthermore, systemic inflammation in $\mathrm{AD}$ is associated with several BBB changes, which further favor amyloid- $\beta$ peptides accumulation into the brain because the injury alters the influx and efflux of the peptides [145]; correspondingly, systemic inflammation accelerates hippocampal amyloid- $\beta$ peptides deposition [146]. Therefore, dysfunction of the BBB might play a significant role in the pathogenesis of vascular dementia induced by SARS-CoV-2 infection, but further observations are needed.

Additionally, damage to the BBB is not the only mechanism where SARS-CoV-2 infection can result in dementia. Some data suggest that amyloid- $\beta$ protein possesses antimicrobial and antiviral activity in vitro [147]. Therefore, the presence of insoluble deposits of amyloid- $\beta$ peptides could be a factor (e.g., genetic predisposing) that alter the response to viral SARS-CoV-2 infection. Thus, it is conceivable that SARS-CoV-2 contributes to BBB damage and also creates a feed-forward effect whereby pathogen-induced damage favors a further spread of the pathogen's transit zones and even the sequential development of the pathology associated to $\mathrm{AD}$ [138].

On the other hand, individuals with $\mathrm{AD}$ are more vulnerable to the effects of peripheral infection, especially SARSCoV-2, mainly due to the association of physical comorbidities. It is more probable that these individuals have cardiovascular disease, diabetes, and pneumonia [148]. Besides, there is an overall decrease in naive $T$ cell diversity after the age of 65 [149-151]; this can limit the capacity of the individual to induce a sufficient immune response to infection. Together, these data indicate the vulnerability of these patients to infection.

\section{Neurological Implications of BBB Disruption by SARS-CoV-2 in Multiple Sclerosis}

Multiple sclerosis (MS) is a chronic inflammatory disease of the CNS, characterized by several pathological processes, including inflammation, trans-endothelial migration, demyelination, axonopathy, and neuron loss mediated by immune cells [152]. MS represents a neurological disease where an infectious agent plays a triggering role, being viruses the most likely culprit in genetically predisposed individuals [141]. There is a presumption that several neurotropic viruses using similar mechanisms could be involved in MS pathogenesis [153]. Some viruses that have been implicated in the development of MS include herpes viruses, paramyxoviruses, picornaviruses, as well as viruses that classically affect the respiratory system such as influenza virus [154].

A critical step in the pathogenesis of MS is the infiltration of autoreactive $\mathrm{CD}^{+}{ }^{+}$T-lymphocytes into the CNS after activation in the periphery. Evaluation of proinflammatory cytokines (IL-1 $\beta$, IL-6, and IL-8), Th1 cytokines (IFN- $\gamma$, TNF- $\alpha$, 


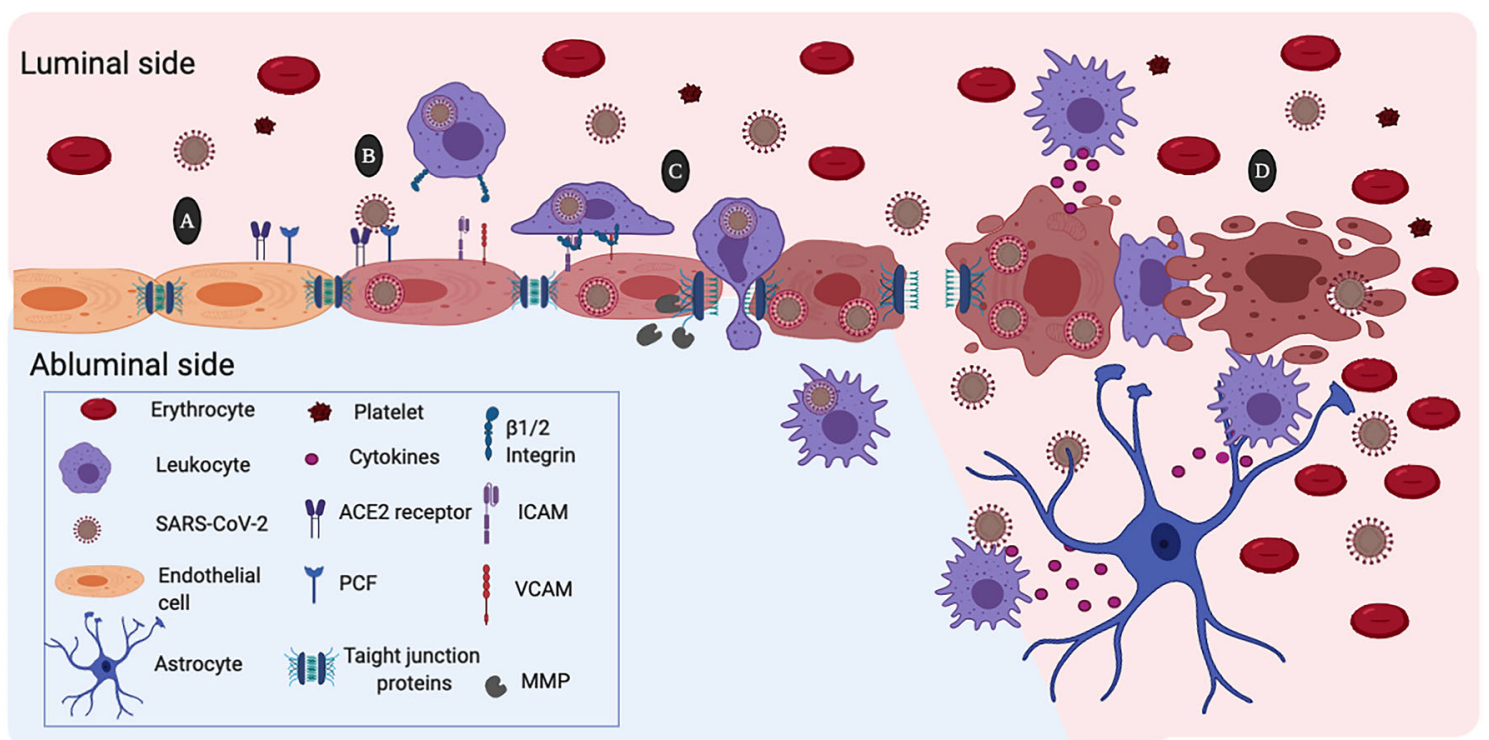

Fig. 2 Possible mechanism of damage to the blood-brain barrier (BBB) by the action of SARS-CoV-2. a Expression of angiotensin-converting enzyme 2 (ACE2) and the pro-protein convertase furin (PCF) in the membrane of the brain microvascular endothelial cells facilitates SARSCoV-2 infection. b SARS-CoV2 infection activates the brain microendothelial cells inducing high expression of the vascular and the intercellular adhesion molecules (VCAM and ICAM). Likewise, SARS$\mathrm{CoV}-2$ induces the expression and activation matrix metalloproteinases (MMP) that degrade tight junctions proteins. $\mathbf{c}$ Recognition of ICAM and ICAM through the $\beta 1$ and $\beta 2$ integrins causes binding of circulating leukocytes to endothelial cells that lead transcellular extravasation. This process facilitate viral entrance to the cerebral parenchyma through the "Trojan horse" mechanism. d SARS-CoV-2 viral replication induces endothelial cell contraction and lysis. Increased permeability of the BBB allows extravasation of plasma proteins and blood cells. Activation of leukocytes and platelets contributes to the BBB damage. Besides, endothelial cell death disturbs the microenvironment of the brain parenchyma allowing free passage of the SARS-CoV-2 virus and infection of other cells of the central nervous system
IL-2, and IL-12), and Th2 cytokines (IL-4, IL-5, and IL-10) in sera collected from SARS patients within 2 days of hospital admission showed a substantial elevation of IL-12, IL-6, IL-8, IL-10, and IFN- $\gamma$ [155]. Also, Sonar et al. [156] revealed that IFN- $\gamma$ favored the trans-endothelial migration of $\mathrm{CD}^{+} \mathrm{T}$ cells from the apical (luminal side) to the basal side (abluminal side) of the endothelial monolayer (Fig. 2). Besides, using multicolor immunofluorescence and confocal microscopic analysis, these authors indicated that IFN- $\gamma$ induce relocalization of ICAM-1, platelet endothelial cell adhesion molecule-1, zona occludens protein 1, and VE-cadherin in the endothelial cells. These findings reveal that the IFN- $\gamma$ produced during the response to infection and inflammation could contribute to the disruption of the $\mathrm{BBB}$ and promote $\mathrm{CD}^{+} \mathrm{T}$ cells brain migration. Interestingly, BBB disruption appears in experimental autoimmune encephalomyelitis, a typical MS model, and the clinical severity is linked to the degree of BBB integrity [157]. Furthermore, imaging studies showed BBB disruption in normal-appearing white matter in MS [158]. This data is important since BBB breakdown precedes the development of new MS lesions [159]. In summary, it is possible that the damage caused by SARS-CoV-2 infection to the endothelial cells also causes loss of the BBB integrity, favoring MS progression.

\section{Conclusion}

Recent information has shown the SARS-CoV-2 ability to infect CNS cells, especially the brain microvascular endothelial cells of the BBB. This situation explains the neurological symptoms observed during infection and reveals the possible consequences of viral infection. Although it is too early to elucidate the long-term side effects of SARS-CoV2 infection, the background obtained with other respiratory viruses suggests that SARS-CoV-2 might induce permanent sequelae in the CNS through damage to the BBB, including dementia in predisposed patients. Furthermore, the proinflammatory state, due to viral infection seems to be the general mechanism involved in the induction of BBB damage. However, further studies are necessary to confirm this evidence.

Acknowledgments We would like to thank the Consejo Nacional de Ciencia y Tecnología (CONACYT) for the scholarship No. 413994 assigned to Iván M. Alquisiras Burgos, doctoral student from Programa de Doctorado en Ciencias Biomédicas, Universidad Nacional Autónoma de México (UNAM). We also thank the postdoctoral fellowship program DGAPA-UNAM assigned to Irlanda Peralta Arrieta at FES-Iztacala, UBIMED, and postdoctoral fellowship N ${ }^{\circ}$ SECTEI/138/2019 from Mexico City assigned to Luis Alonso Palomares. 
Authors' Contributions All authors contributed substantially to research data and discussion of the content, wrote and reviewed the article, and edited the manuscript before submission.

\section{Compliance with Ethical Standards}

Conflict of Interest The authors declare that they have no conflict of interests.

\section{References}

1. Cui J, Li F, Shi Z-L (2019) Origin and evolution of pathogenic coronaviruses. Nat Rev Microbiol 17(3):181-192. https://doi.org/ 10.1038/s41579-018-0118-9

2. Forni D, Cagliani R, Clerici M, Sironi M (2017) Molecular evolution of human coronavirus genomes. Trends Microbiol 25(1): 35-48. https://doi.org/10.1016/j.tim.2016.09.001

3. Su S, Wong G, Shi W, Liu J, Lai ACK, Zhou J, Liu W, Bi Y et al (2016) Epidemiology, genetic recombination, and pathogenesis of coronaviruses. Trends Microbiol 24(6):490-502. https://doi.org/ 10.1016/j.tim.2016.03.003

4. Drosten C, Günther S, Preiser W, van der Werf S, Brodt H-R, Becker S, Rabenau H, Panning M et al (2003) Identification of a novel coronavirus in patients with severe acute respiratory syndrome. N Engl J Med 348(20):1967-1976. https://doi.org/10. 1056/NEJMoa030747

5. Zaki AM, van Boheemen S, Bestebroer TM, Osterhaus ADME, Fouchier RAM (2012) Isolation of a novel coronavirus from a man with pneumonia in Saudi Arabia. N Engl J Med 367(19): 1814-1820. https://doi.org/10.1056/NEJMoa1211721

6. Wu F, Zhao S, Yu B, Chen Y-M, Wang W, Song Z-G, Hu Y, Tao $\mathrm{Z}-\mathrm{W}$ et al (2020) A new coronavirus associated with human respiratory disease in China. Nature 579(7798):265-269. https://doi. org/10.1038/s41586-020-2008-3

7. Chan JF-W, Yuan S, Kok K-H, To KK-W, Chu H, Yang J, Xing F, Liu J et al (2020) A familial cluster of pneumonia associated with the 2019 novel coronavirus indicating person-to-person transmission: A study of a family cluster. Lancet 395(10223): 514-523. https://doi.org/10.1016/S0140-6736(20)30154-9

8. Zhou P, Yang X-L, Wang X-G, Hu B, Zhang L, Zhang W, Si H-R, Zhu Y et al (2020) A pneumonia outbreak associated with a new coronavirus of probable bat origin. Nature 579(7798):270-273. https://doi.org/10.1038/s41586-020-2012-7

9. Lam TT-Y, Shum MH-H, Zhu H-C, Tong Y-G, Ni X-B, Liao YS, Wei W, Cheung WY-M et al (2020) Identification of 2019$\mathrm{nCoV}$ related coronaviruses in Malayan pangolins in southern China. bioRxiv 2020.2002.2013:945485. https://doi.org/10. 1101/2020.02.13.945485

10. Xiao K, Zhai J, Feng Y, Zhou N, Zhang X, Zou J-J, Li N, Guo Y et al (2020) Isolation of SARS-CoV-2-related coronavirus from Malayan pangolins. Nature 583(7815):286-289. https://doi.org/ 10.1038/s41586-020-2313-x

11. Zhang $\mathrm{T}, \mathrm{Wu} \mathrm{Q}$, Zhang $\mathrm{Z}$ (2020) Probable pangolin origin of SARS-CoV-2 associated with the COVID-19 outbreak. Curr Biol 30(7):1346-1351.e1342

12. Liu Y, Gayle AA, Wilder-Smith A, Rocklöv J (2020) The reproductive number of COVID-19 is higher compared to SARS coronavirus. J Travel Med 27(2). https://doi.org/10.1093/jtm/taaa021

13. Chen J (2020) Pathogenicity and transmissibility of 2019-nCoVA quick overview and comparison with other emerging viruses. Microbes Infect 22(2):69-71. https://doi.org/10.1016/j.micinf. 2020.01.004
14. Liu J, Liao X, Qian S, Yuan J, Wang F, Liu Y, Wang Z, Wang FS et al (2020) Community transmission of severe acute respiratory syndrome coronavirus 2, Shenzhen, China, 2020. Emerg Infect Dis 26(6):1320-1323. https://doi.org/10.3201/eid2606.200239

15. Ong SWX, Tan YK, Chia PY, Lee TH, Ng OT, Wong MSY, Marimuthu K (2020) Air, surface environmental, and personal protective equipment contamination by severe acute respiratory syndrome coronavirus 2 (SARS-CoV-2) from a symptomatic patient. JAMA 323(16):1610-1612. https://doi.org/10.1001/jama. 2020.3227

16. van Doremalen N, Bushmaker T, Morris DH, Holbrook MG, Gamble A, Williamson BN, Tamin A, Harcourt JL et al (2020) Aerosol and surface stability of SARS-CoV-2 as compared with SARS-CoV-1. N Engl J Med 382(16):1564-1567. https://doi.org/ 10.1056/NEJMc2004973

17. Xia J, Tong J, Liu M, Shen Y, Guo D (2020) Evaluation of coronavirus in tears and conjunctival secretions of patients with SARSCoV-2 infection. J Med Virol 92(6):589-594. https://doi.org/10. 1002/jmv. 25725

18. Xiao F, Tang M, Zheng X, Liu Y, Li X, Shan H (2020) Evidence for gastrointestinal infection of SARS-CoV-2. Gastroenterology 158(6):1831-1833.e1833. https://doi.org/10.1053/j.gastro.2020. 02.055

19. Chen N, Zhou M, Dong X, Qu J, Gong F, Han Y, Qiu Y, Wang J et al (2020) Epidemiological and clinical characteristics of 99 cases of 2019 novel coronavirus pneumonia in Wuhan, China: a descriptive study. Lancet 395(10223):507-513. https://doi.org/10. 1016/S0140-6736(20)30211-7

20. Li Q, Guan X, Wu P, Wang X, Zhou L, Tong Y, Ren R, Leung KSM et al (2020) Early transmission dynamics in Wuhan, China, of novel coronavirus-infected pneumonia. N Engl J Med 382(13): 1199-1207. https://doi.org/10.1056/NEJMoa2001316

21. Wang D, Hu B, Hu C, Zhu F, Liu X, Zhang J, Wang B, Xiang H et al (2020) Clinical characteristics of 138 hospitalized patients with 2019 novel coronavirus-infected pneumonia in Wuhan, China. JAMA 323(11):1061-1069. https://doi.org/10.1001/jama. 2020.1585

22. Wu Z, McGoogan JM (2020) Characteristics of and important lessons from the coronavirus disease 2019 (COVID-19) outbreak in China: summary of a report of 72314 cases from the Chinese Center for Disease Control and Prevention. JAMA 323(13):1239 1242. https://doi.org/10.1001/jama.2020.2648

23. Zhou F, Yu T, Du R, Fan G, Liu Y, Liu Z, Xiang J, Wang Y et al (2020) Clinical course and risk factors for mortality of adult inpatients with COVID-19 in Wuhan, China: a retrospective cohort study. Lancet 395(10229):1054-1062. https://doi.org/10.1016/ S0140-6736(20)30566-3

24. Chen Z-M, Fu J-F, Shu Q (2020) New coronavirus: new challenges for pediatricians. World J Pediatr 16(3):222-222. https:// doi.org/10.1007/s12519-020-00346-4

25. Chen Z-M, Fu J-F, Shu Q, Chen Y-H, Hua C-Z, Li F-B, Lin R, Tang L-F et al (2020) Diagnosis and treatment recommendations for pediatric respiratory infection caused by the 2019 novel coronavirus. World J Pediatr 16(3):240-246. https://doi.org/10.1007/ s12519-020-00345-5

26. Sun D, Li H, Lu X-X, Xiao H, Ren J, Zhang F-R, Liu Z-S (2020) Clinical features of severe pediatric patients with coronavirus disease 2019 in Wuhan: a single center's observational study. World J Pediatr 16(3):251-259. https://doi.org/10.1007/s12519-02000354-4

27. Wei M, Yuan J, Liu Y, Fu T, Yu X, Zhang Z-J (2020) Novel coronavirus infection in hospitalized infants under 1 year of age in China. JAMA 323(13):1313-1314. https://doi.org/10.1001/ jama.2020.2131

28. W-j G, Ni Z-y HY, Liang W-h, C-q O, He J-x, Liu L, Shan H, C-1 L et al (2020) Clinical characteristics of coronavirus disease 2019 
in China. N Engl J Med 382(18):1708-1720. https://doi.org/10. 1056/NEJMoa2002032

29. Goyal P, Choi JJ, Pinheiro LC, Schenck EJ, Chen R, Jabri A, Satlin MJ, Campion TR et al (2020) Clinical characteristics of Covid-19 in New York City. N Engl J Med 382(24):2372-2374. https://doi.org/10.1056/NEJMc2010419

30. Huang C, Wang Y, Li X, Ren L, Zhao J, Hu Y, Zhang L, Fan G et al (2020) Clinical features of patients infected with 2019 novel coronavirus in Wuhan, China. Lancet 395(10223):497-506. https://doi.org/10.1016/S0140-6736(20)30183-5

31. Wan S, Xiang Y, Fang W, Zheng Y, Li B, Hu Y, Lang C, Huang $\mathrm{D}$ et al (2020) Clinical features and treatment of COVID-19 patients in Northeast Chongqing. J Med Virol 92(7):797-806. https://doi.org/10.1002/jmv. 25783

32. Chen X, Tang Y, Mo Y, Li S, Lin D, Yang Z, Yang Z, Sun H et al (2020) A diagnostic model for coronavirus disease 2019 (COVID19) based on radiological semantic and clinical features: A multicenter study. Eur Radiol. https://doi.org/10.1007/s00330-02006829-2

33. Cheng Z, Lu Y, Cao Q, Qin L, Pan Z, Yan F, Yang W (2020) Clinical features and chest $\mathrm{CT}$ manifestations of coronavirus disease 2019 (COVID-19) in a single-center study in Shanghai, China. Am J Roentgenol 215(1):121-126. https://doi.org/10. 2214/AJR.20.22959

34. Mao L, Jin H, Wang M, Hu Y, Chen S, He Q, Chang J, Hong C et al (2020) Neurologic manifestations of hospitalized patients with coronavirus disease 2019 in Wuhan, China. JAMA Neurol 77(6):1-9. https://doi.org/10.1001/jamaneurol.2020.1127

35. Eliezer M, Hautefort C, Hamel A-L, Verillaud B, Herman P, Houdart E, Eloit C (2020) Sudden and complete olfactory loss of function as a possible symptom of COVID-19. JAMA Otolaryngol Head Neck Surg 146(7):674-675. https://doi.org/ 10.1001/jamaoto.2020.0832

36. Klopfenstein T, Kadiane-Oussou NJ, Toko L, Royer PY, Lepiller Q, Gendrin V, Zayet S (2020) Features of anosmia in COVID-19. Med Mal Infect 50(5):436-439. https://doi.org/10.1016/j.medmal. 2020.04.006

37. Paterson RW, Brown RL, Benjamin L, Nortley R, Wiethoff S, Bharucha T, Jayaseelan DL, Kumar G et al (2020) The emerging spectrum of COVID-19 neurology: Clinical, radiological and laboratory findings. Brain J Neurol 8:awaa240. https://oi.org/10. 1093/brain/awaa240

38. Zubair AS, McAlpine LS, Gardin T, Farhadian S, Kuruvilla DE, Spudich S (2020) Neuropathogenesis and neurologic manifestations of the coronaviruses in the age of coronavirus disease 2019: A review. JAMA Neurol 77(8):1018-1027. https://doi.org/10. 1001/jamaneurol.2020.2065

39. Bohmwald K, Gálvez NMS, Ríos M, Kalergis AM (2018) Neurologic alterations due to respiratory virus infections. Front Cell Neurosci 12(386). https://doi.org/10.3389/fncel.2018.00386

40. Ding Y, Wang H, Shen H, Li Z, Geng J, Han H, Cai J, Li X et al (2003) The clinical pathology of severe acute respiratory syndrome (SARS): A report from China. J Pathol 200(3):282-289. https://doi.org/10.1002/path.1440

41. Montalvan V, Lee J, Bueso T, De Toledo J, Rivas K (2020) Neurological manifestations of COVID-19 and other coronavirus infections: a systematic review. Clin Neurol Neurosurg 194: 105921. https://doi.org/10.1016/j.clineuro.2020.105921

42. Arbour N, Côté G, Lachance C, Tardieu M, Cashman NR, Talbot PJ (1999) Acute and persistent infection of human neural cell lines by human coronavirus OC43. J Virol 73(4):3338-3350. https:// doi.org/10.1128/JVI.73.4.3338-3350.1999

43. Jacomy H, Talbot PJ (2003) Vacuolating encephalitis in mice infected by human coronavirus OC43. Virology 315(1):20-33. https://doi.org/10.1016/s0042-6822(03)00323-4
44. Gu J, Gong E, Zhang B, Zheng J, Gao Z, Zhong Y, Zou W, Zhan J et al (2005) Multiple organ infection and the pathogenesis of SARS. J Exp Med 202(3):415-424. https://doi.org/10.1084/jem. 20050828

45. Moriguchi T, Harii N, Goto J, Harada D, Sugawara H, Takamino J, Ueno M, Sakata H et al (2020) A first case of meningitis/ encephalitis associated with SARS-coronavirus-2. Int J Infect Dis 94:55-58. https://doi.org/10.1016/j.ijid.2020.03.062

46. Avula A, Nalleballe K, Narula N, Sapozhnikov S, Dandu V, Toom S, Glaser A, Elsayegh D (2020) COVID-19 presenting as stroke. Brain Behav Immun 87:115-119. https://doi.org/10.1016/ j.bbi.2020.04.077

47. Al Saiegh F, Ghosh R, Leibold A, Avery MB, Schmidt RF, Theofanis T, Mouchtouris N, Philipp L et al (2020) Status of SARS-CoV-2 in cerebrospinal fluid of patients with COVID-19 and stroke. Journal of neurology, neurosurgery \&amp. Psychiatry 91(8):846-848. https://doi.org/10.1136/jnnp-2020-323522

48. Oxley TJ, Mocco J, Majidi S, Kellner CP, Shoirah H, Singh IP, De Leacy RA, Shigematsu T et al (2020) Large-vessel stroke as a presenting feature of Covid-19 in the young. N Engl J Med 382(20):e60. https://doi.org/10.1056/NEJMc2009787

49. Duong L, Xu P, Liu A (2020) Meningoencephalitis without respiratory failure in a young female patient with COVID-19 infection in downtown Los Angeles, early April 2020. Brain Behav Immun 87:33-33. https://doi.org/10.1016/j.bbi.2020.04.024

50. Gutiérrez-Ortiz C, Méndez-Guerrero A, Rodrigo-Rey S, San Pedro-Murillo E, Bermejo-Guerrero L, Gordo-Mañas R, de Aragón-Gómez F, Benito-León J (2020) Miller fisher syndrome and polyneuritis cranialis in COVID-19. Neurology 95(5):e601e605. https://doi.org/10.1212/wnl.0000000000009619

51. Zhao H, Shen D, Zhou H, Liu J, Chen S (2020) Guillain-Barre syndrome associated with SARS-CoV-2 infection: causality or coincidence? Lancet Neurol 19(5):383-384. https://doi.org/10. 1016/S1474-4422(20)30109-5

52. Sedaghat Z, Karimi N (2020) Guillain Barre syndrome associated with COVID-19 infection: a case report. J Clin Neurosci 76:233235. https://doi.org/10.1016/j.jocn.2020.04.062

53. Toscano G, Palmerini F, Ravaglia S, Ruiz L, Invernizzi P, Cuzzoni MG, Franciotta D, Baldanti F et al (2020) GuillainBarré syndrome associated with SARS-CoV-2. N Engl J Med 382(26):2574-2576. https://doi.org/10.1056/NEJMc2009191

54. Virani A, Rabold E, Hanson T, Haag A, Elrufay R, Cheema T, Balaan M, Bhanot N (2020) Guillain-Barré syndrome associated with SARS-CoV-2 infection. IDCases 20:e00771-e00771. https:// doi.org/10.1016/j.idcr.2020.e00771

55. Poyiadji N, Shahin G, Noujaim D, Stone M, Patel S, Griffith B (2020) COVID-19-associated acute hemorrhagic necrotizing encephalopathy: imaging features. Radiology 296(2):E119-E120. https://doi.org/10.1148/radiol.2020201187

56. Dubé M, Le Coupanec A, Wong AHM, Rini JM, Desforges M, Talbot PJ (2018) Axonal transport enables neuron-to-neuron propagation of human coronavirus OC43. J Virol 92(17):e00404e00418. https://doi.org/10.1128/jvi.00404-18

57. Netland J, Meyerholz DK, Moore S, Cassell M, Perlman S (2008) Severe acute respiratory syndrome coronavirus infection causes neuronal death in the absence of encephalitis in mice transgenic for human ACE2. J Virol 82(15):7264-7275. https://doi.org/10. 1128/jvi.00737-08

58. Spindler KR, Hsu TH (2012) Viral disruption of the blood-brain barrier. Trends Microbiol 20(6):282-290. https://doi.org/10.1016/ j.tim.2012.03.009

59. Albright AV, Soldan SS, González-Scarano F (2003) Pathogenesis of human immunodeficiency virus-induced neurological disease. J Neuro-Oncol 9(2):222-227. https://doi.org/10. $1080 / 13550280390194073$ 
60. Desforges M, Miletti TC, Gagnon M, Talbot PJ (2007) Activation of human monocytes after infection by human coronavirus 229E. Virus Res 130(1-2):228-240. https://doi.org/10.1016/j.virusres. 2007.06.016

61. Li Z, Liu T, Yang N, Han D, Mi X, Li Y, Liu K, Vuylsteke A et al (2020) Neurological manifestations of patients with COVID-19: potential routes of SARS-CoV-2 neuroinvasion from the periphery to the brain. Front Med:1-9. https://doi.org/10.1007/s11684020-0786-5

62. Walls AC, Park Y-J, Tortorici MA, Wall A, McGuire AT, Veesler D (2020) Structure, function, and antigenicity of the SARS-CoV-2 spike glycoprotein. Cell 181(2):281-292.e286. https://doi.org/10. 1016/j.cell.2020.02.058

63. Li W, Zhang C, Sui J, Kuhn JH, Moore MJ, Luo S, Wong S-K, Huang IC et al (2005) Receptor and viral determinants of SARScoronavirus adaptation to human ACE2. EMBO J 24(8):1634 1643. https://doi.org/10.1038/sj.emboj.7600640

64. Abiodun OA, Ola MS (2020) Role of brain renin angiotensin system in neurodegeneration: An update. Saudi J Biol Sci 27(3): 905-912. https://doi.org/10.1016/j.sjbs.2020.01.026

65. Ou Z, Jiang T, Gao Q, Tian Y-Y, Zhou J-S, Wu L, Shi J-Q, Zhang Y-D (2016) Mitochondrial-dependent mechanisms are involved in angiotensin II-induced apoptosis in dopaminergic neurons. J Renin-Angiotensin-Aldosterone Syst 17(4):1470320316672349. https://doi.org/10.1177/1470320316672349

66. Chen R, Wang K, Yu J, Chen Z, Wen C, Xu Z (2020) The spatial and cell-type distribution of SARS-CoV-2 receptor ACE2 in human and mouse brain. bioRxiv:2020.2004.2007.030650. doi: https://doi.org/10.1101/2020.04.07.030650

67. Wang W, Xu Y, Gao R, Lu R, Han K, Wu G, Tan W (2020) Detection of SARS-CoV-2 in different types of clinical specimens. JAMA 323(18):1843-1844. https://doi.org/10.1001/jama. 2020.3786

68. Lavoie JL, Cassell MD, Gross KW, Sigmund CD (2004) Adjacent expression of renin and angiotensinogen in the rostral ventrolateral medulla using a dual-reporter transgenic model. Hypertension 43(5):1116-1119. https://doi.org/10.1161/01.hyp.0000125143. 73301.94

69. Stornetta RL, Hawelu-Johnson CL, Guyenet PG, Lynch KR (1988) Astrocytes synthesize angiotensinogen in brain. Science (New York, NY) 242(4884):1444-1446. https://doi.org/10.1126/ science. 3201232

70. Dzau VJ, Ingelfinger J, Pratt RE, Ellison KE (1986) Identification of renin and angiotensinogen messenger RNA sequences in mouse and rat brains. Hypertension 8(6):544-548. https://doi. org/10.1161/01.HYP.8.6.544

71. Gembardt F, Sterner-Kock A, Imboden H, Spalteholz M, Reibitz F, Schultheiss H-P, Siems W-E, Walther T (2005) Organ-specific distribution of ACE2 mRNA and correlating peptidase activity in rodents. Peptides 26(7):1270-1277. https://doi.org/10.1016/j. peptides.2005.01.009

72. Harmer D, Gilbert M, Borman R, Clark KL (2002) Quantitative mRNA expression profiling of ACE 2, a novel homologue of angiotensin converting enzyme. FEBS Lett 532(1):107-110. https://doi.org/10.1016/S0014-5793(02)03640-2

73. Chappell MC, Brosnihan KB, Diz DI, Ferrario CM (1989) Identification of angiotensin-(1-7) in rat brain. Evidence for differential processing of angiotensin peptides. J Biol Chem 264(28): $16518-16523$

74. Hamming I, Timens W, Bulthuis MLC, Lely AT, Navis GJ, van Goor H (2004) Tissue distribution of ACE2 protein, the functional receptor for SARS coronavirus. A first step in understanding SARS pathogenesis. J Pathol 203(2):631-637. https://doi.org/10. 1002/path. 1570
75. Bodiga VL, Bodiga S (2013) Renin angiotensin system in cognitive function and dementia. Asian J Neurosci 2013:102602. https://doi.org/10.1155/2013/102602

76. Gowrisankar YV, Clark MA (2016) Angiotensin II regulation of angiotensin-converting enzymes in spontaneously hypertensive rat primary astrocyte cultures. J Neurochem 138(1):74-85. https://doi.org/10.1111/jnc. 13641

77. Albini A, Di Guardo G, Noonan DM, Lombardo M (2020) The SARS-CoV-2 receptor, ACE-2, is expressed on many different cell types: implications for ACE-inhibitor- and angiotensin II receptor blocker-based cardiovascular therapies. Intern Emerg Med 15(5):759-766. https://doi.org/10.1007/s11739-020-02364-6

78. Bestle D, Heindl MR, Limburg H, van TVL, Pilgram O, Moulton H, Stein DA, Hardes K, Eickmann M, Dolnik O, Rohde C, Becker S, Klenk H-D, Garten W, Steinmetzer T, Böttcher-Friebertshäuser E (2020) TMPRSS2 and furin are both essential for proteolytic activation and spread of SARS-CoV-2 in human airway epithelial cells and provide promising drug targets. bioRxiv: 2020.2004.2015.042085. doi:https://doi.org/10.1101/2020.04.15. 042085

79. Shang J, Ye G, Shi K, Wan Y, Luo C, Aihara H, Geng Q, Auerbach A et al (2020) Structural basis of receptor recognition by SARS-CoV-2. Nature 581(7807):221-224. https://doi.org/10. 1038/s41586-020-2179-y

80. Thomas G (2002) Furin at the cutting edge: from protein traffic to embryogenesis and disease. Nat Rev Mol Cell Biol 3(10):753766. https://doi.org/10.1038/nrm934

81. Jin X, Xu K, Jiang P, Lian J, Hao S, Yao H, Jia H, Zhang Y et al (2020) Virus strain from a mild COVID-19 patient in Hangzhou represents a new trend in SARS-CoV-2 evolution potentially related to Furin cleavage site. Emerg Microbes Infect 9(1):1474 1488. https://doi.org/10.1080/22221751.2020.1781551

82. Cheng J, Zhao Y, Xu G, Zhang K, Jia W, Sun Y, Zhao J, Xue J et al (2019) The S2 subunit of QX-type infectious bronchitis coronavirus spike protein is an essential determinant of Neurotropism. Viruses 11(10):972. https://doi.org/10.3390/ v11100972

83. Le Coupanec A, Desforges M, Meessen-Pinard M, Dubé M, Day R, Seidah NG, Talbot PJ (2015) Cleavage of a neuroinvasive human respiratory virus spike glycoprotein by proprotein convertases modulates neurovirulence and virus spread within the central nervous system. PLoS Pathog 11(11):e1005261e1005261. https://doi.org/10.1371/journal.ppat.1005261

84. Keaney J, Campbell M (2015) The dynamic blood-brain barrier. FEBS J 282(21):4067-4079. https://doi.org/10.1111/febs.13412

85. Besancon E, Guo S, Lok J, Tymianski M, Lo EH (2008) Beyond NMDA and AMPA glutamate receptors: Emerging mechanisms for ionic imbalance and cell death in stroke. Trends Pharmacol Sci 29(5):268-275. https://doi.org/10.1016/j.tips.2008.02.003

86. O'Donnell ME (2014) Chapter four - blood-brain barrier Na transporters in ischemic stroke. In: Davis TP (ed) Advances in Pharmacology, vol 71. Academic press, Cambridge, pp. 113146. https://doi.org/10.1016/bs.apha.2014.06.011

87. Chiu C-F, Chu L-W, Liao I-C, Simanjuntak Y, Lin Y-L, Juan CC, Ping Y-H (2020) The mechanism of the Zika virus crossing the placental barrier and the blood-brain barrier. Front Microbiol 11(214). https://doi.org/10.3389/fmicb.2020.00214

88. Verma S, Lo Y, Chapagain M, Lum S, Kumar M, Gurjav U, Luo $\mathrm{H}$, Nakatsuka A et al (2009) West Nile virus infection modulates human brain microvascular endothelial cells tight junction proteins and cell adhesion molecules: Transmigration across the in vitro blood-brain barrier. Virology 385(2):425-433. https:// doi.org/10.1016/j.virol.2008.11.047

89. Leda AR, Bertrand L, Andras IE, El-Hage N, Nair M, Toborek M (2019) Selective disruption of the blood-brain barrier by Zika 
virus. Front Microbiol 10:2158. https://doi.org/10.3389/fmicb. 2019.02158

90. Wells AI, Coyne CB (2018) Type III interferons in antiviral defenses at barrier surfaces. Trends Immunol 39(10):848-858. https://doi.org/10.1016/j.it.2018.08.008

91. Bleau C, Filliol A, Samson M, Lamontagne L (2015) Brain invasion by mouse hepatitis virus depends on impairment of tight junctions and beta interferon production in brain microvascular endothelial cells. J Virol 89(19):9896-9908. https://doi.org/10. 1128/jvi.01501-15

92. Desforges M, Le Coupanec A, Brison E, Meessen-Pinard M, Talbot PJ (2014) Neuroinvasive and neurotropic human respiratory coronaviruses: potential neurovirulent agents in humans. Adv Exp Med Biol 807:75-96. https://doi.org/10.1007/978-81-3221777-0 6

93. Guo Y, Korteweg C, McNutt MA, Gu J (2008) Pathogenetic mechanisms of severe acute respiratory syndrome. Virus Res 133(1):4-12. https://doi.org/10.1016/j.virusres.2007.01.022

94. Paniz-Mondolfi A, Bryce C, Grimes Z, Gordon RE, Reidy J, Lednicky J, Sordillo EM, Fowkes M (2020) Central nervous system involvement by severe acute respiratory syndrome coronavirus-2 (SARS-CoV-2). J Med Virol 92(7):699-702. https://doi.org/10.1002/jmv.25915

95. Xu J, Zhong S, Liu J, Li L, Li Y, Wu X, Li Z, Deng P et al (2005) Detection of severe acute respiratory syndrome coronavirus in the brain: Potential role of the chemokine mig in pathogenesis. Clin Infect Dis 41(8):1089-1096. https://doi.org/10.1086/444461

96. Desforges M, Le Coupanec A, Stodola JK, Meessen-Pinard M, Talbot PJ (2014) Human coronaviruses: Viral and cellular factors involved in neuroinvasiveness and neuropathogenesis. Virus Res 194:145-158. https://doi.org/10.1016/j.virusres.2014.09.011

97. Suen WW, Prow NA, Hall RA, Bielefeldt-Ohmann H (2014) Mechanism of West Nile virus neuroinvasion: a critical appraisal. Viruses 6(7):2796-2825. https://doi.org/10.3390/v6072796

98. Xanthos DN, Sandkühler J (2014) Neurogenic neuroinflammation: inflammatory CNS reactions in response to neuronal activity. Nat Rev Neurosci 15(1):43-53. https://doi.org/10.1038/nrn3617

99. Almutairi MM, Gong C, Xu YG, Chang Y, Shi H (2016) Factors controlling permeability of the blood-brain barrier. Cell Mol Life Sci 73(1):57-77. https://doi.org/10.1007/s00018-015-2050-8

100. Erickson MA, Dohi K, Banks WA (2012) Neuroinflammation: a common pathway in CNS diseases as mediated at the blood-brain barrier. Neuroimmunomodulation 19(2):121-130. https://doi.org/ $10.1159 / 000330247$

101. Zhang H, Zhou P, Wei Y, Yue H, Wang Y, Hu M, Zhang S, Cao T et al (2020) Histopathologic changes and SARS-CoV-2 immunostaining in the lung of a patient with COVID-19. Ann Intern Med 172(9):629-632. https://doi.org/10.7326/M20-0533

102. Engelhardt B, Ransohoff RM (2012) Capture, crawl, cross: the T cell code to breach the blood-brain barriers. Trends Immunol 33(12):579-589. https://doi.org/10.1016/j.it.2012.07.004

103. Gorina R, Lyck R, Vestweber D, Engelhardt B (2014) $\beta<$ sub $>2</$ sub $>$ integrin-mediated crawling on endothelial ICAM-1 and ICAM-2 is a prerequisite for transcellular neutrophil diapedesis across the inflamed blood-brain barrier. J Immunol 192(1):324 337. https://doi.org/10.4049/jimmunol.1300858

104. Hermand P, Huet M, Callebaut I, Gane P, Ihanus E, Gahmberg CG, Cartron JP, Bailly P (2000) Binding sites of leukocyte beta 2 integrins (LFA-1, mac-1) on the human ICAM-4/LW blood group protein. J Biol Chem 275(34):26002-26010. https://doi.org/10. 1074/jbc.M002823200

105. Majerova P, Michalicova A, Cente M, Hanes J, Vegh J, Kittel A, Kosikova N, Cigankova V et al (2019) Trafficking of immune cells across the blood-brain barrier is modulated by neurofibrillary pathology in tauopathies. PLoS One 14(5):e0217216. https://doi. org/10.1371/journal.pone. 0217216
106. Randi AM, Hogg N (1994) I domain of beta 2 integrin lymphocyte function-associated antigen-1 contains a binding site for ligand intercellular adhesion molecule-1. J Biol Chem 269(17):1239512398

107. van Wetering S, van den Berk N, van Buul JD, Mul FP, Lommerse I, Mous R, ten Klooster JP, Zwaginga JJ et al (2003) VCAM-1mediated Rac signaling controls endothelial cell-cell contacts and leukocyte transmigration. Am J Phys Cell Phys 285(2):C343C352. https://doi.org/10.1152/ajpcell.00048.2003

108. Park WB, Kwon NJ, Choi SJ, Kang CK, Choe PG, Kim JY, Yun J, Lee GW et al (2020) Virus isolation from the first patient with SARS-CoV-2 in Korea. J Korean Med Sci 35(7):e84. https://doi. org/10.3346/jkms.2020.35.e84

109. Yilla M, Harcourt BH, Hickman CJ, McGrew M, Tamin A, Goldsmith CS, Bellini WJ, Anderson LJ (2005) SARScoronavirus replication in human peripheral monocytes/macrophages. Virus Res 107(1):93-101. https://doi.org/10.1016/j. virusres.2004.09.004

110. Azkur AK, Akdis M, Azkur D, Sokolowska M, van de Veen W, Brüggen M-C, O'Mahony L, Gao Y et al (2020) Immune response to SARS-CoV-2 and mechanisms of immunopathological changes in COVID-19. Allergy 75(7):1564-1581. https://doi.org/10. 1111/all.14364

111. Chang Y-S, Ko B-H, Ju J-C, Chang H-H, Huang S-H, Lin C-W (2020) SARS unique domain (SUD) of severe acute respiratory syndrome coronavirus induces NLRP3 Inflammasome-dependent CXCL10-mediated pulmonary inflammation. Int J Mol Sci 21(9): 3179. https://doi.org/10.3390/ijms21093179

112. Brenner SR Erythropoietin-induced hemoglobin subunit beta may stimulate innate immune RNA virus pattern recognition, suppress reactive oxygen species, reduce ACE2 viral doorway opening, and neutrophil extracellular traps against COVID-19. In: Journal of Medical Virology. https://doi.org/10.1002/jmv.26284

113. Hur S (2019) Double-stranded RNA sensors and modulators in innate immunity. Annu Rev Immunol 37:349-375. https://doi.org/ 10.1146/annurev-immunol-042718-041356

114. Hadjadj J, Yatim N, Barnabei L, Corneau A, Boussier J, Smith N, Péré H, Charbit B et al (2020) Impaired type I interferon activity and inflammatory responses in severe COVID-19 patients. Science (New York, NY) 369(6504):718-724. https://doi.org/10. 1126/science.abc6027

115. Kindler E, Thiel V (2016) SARS-CoV and IFN: too little, too late. Cell Host Microbe 19(2):139-141. https://doi.org/10.1016/j. chom.2016.01.012

116. Wu C, Chen X, Cai Y, Ja X, Zhou X, Xu S, Huang H, Zhang L et al (2020) Risk factors associated with acute respiratory distress syndrome and death in patients with coronavirus disease 2019 pneumonia in Wuhan, China. JAMA Intern Med 180(7):1-11. https://doi.org/10.1001/jamainternmed.2020.0994

117. Ye Q, Wang B, Mao J (2020) The pathogenesis and treatment of the 'cytokine storm' in COVID-19. J Infect 80(6):607-613. https:// doi.org/10.1016/j.jinf.2020.03.037

118. Xu Z, Shi L, Wang Y, Zhang J, Huang L, Zhang C, Liu S, Zhao P et al (2020) Pathological findings of COVID-19 associated with acute respiratory distress syndrome. Lancet Respir Med 8(4):420 422. https://doi.org/10.1016/S2213-2600(20)30076-X

119. Qin C, Zhou L, Hu Z, Zhang S, Yang S, Tao Y, Xie C, Ma K et al (2020) Dysregulation of immune response in patients with coronavirus 2019 (COVID-19) in Wuhan, China. Clin Infect Dis 71(15):762-768. https://doi.org/10.1093/cid/ciaa248

120. Wang L, Li X, Chen H, Yan S, Li Y, Li D, Gong Z (2020) SARSCoV-2 infection does not significantly cause acute renal injury: an analysis of 116 hospitalized patients with COVID-19 in a single hospital, Wuhan, China. medRxiv:2020 2002(2019):20025288. https://doi.org/10.1101/2020.02.19.20025288 
121. Connors JM, Levy JH (2020) COVID-19 and its implications for thrombosis and anticoagulation. Blood 135(23):2033-2040. https://doi.org/10.1182/blood.2020006000

122. Jackson SP, Darbousset R, Schoenwaelder SM (2019) Thromboinflammation: challenges of therapeutically targeting coagulation and other host defense mechanisms. Blood 133(9): 906-918. https://doi.org/10.1182/blood-2018-11-882993

123. Varga Z, Flammer AJ, Steiger P, Haberecker M, Andermatt R, Zinkernagel AS, Mehra MR, Schuepbach RA et al (2020) Endothelial cell infection and endotheliitis in COVID-19. Lancet 395(10234):1417-1418. https://doi.org/10.1016/S0140-6736(20) 30937-5

124. Tetro JA (2020) Is COVID-19 receiving ADE from other coronaviruses? Microbes Infect 22(2):72-73. https://doi.org/10. 1016/j.micinf.2020.02.006

125. Zhu Z, Chakraborti S, He Y, Roberts A, Sheahan T, Xiao X, Hensley LE, Prabakaran P et al (2007) Potent cross-reactive neutralization of SARS coronavirus isolates by human monoclonal antibodies. Proc Natl Acad Sci 104(29):12123-12128. https:// doi.org/10.1073/pnas.0701000104

126. Nimmerjahn F, Ravetch JV (2008) Fcgamma receptors as regulators of immune responses. Nat Rev Immunol 8(1):34-47. https:// doi.org/10.1038/nri2206

127. Grifoni A, Weiskopf D, Ramirez SI, Mateus J, Dan JM, Moderbacher CR, Rawlings SA, Sutherland A et al (2020) Targets of $\mathrm{T}$ cell responses to SARS-CoV-2 coronavirus in humans with COVID-19 disease and unexposed individuals. Cell 181(7):1489-1501 e1415. https://doi.org/10.1016/j.cell. 2020.05.015

128. Jansen JM, Gerlach T, Elbahesh H, Rimmelzwaan GF, Saletti G (2019) Influenza virus-specific CD4+ and CD8+ T cell-mediated immunity induced by infection and vaccination. J Clin Virol 119: 44-52. https://doi.org/10.1016/j.jcv.2019.08.009

129. Braun J, Loyal L, Frentsch M, Wendisch D, Georg P, Kurth F, Hippenstiel S, Dingeldey M et al (2020) SARS-CoV-2-reactive T cells in healthy donors and patients with COVID-19. Nature. https://doi.org/10.1038/s41586-020-2598-9

130. Le Bert N, Tan AT, Kunasegaran K, Tham CYL, Hafezi M, Chia A, Chng MHY, Lin M et al (2020) SARS-CoV-2-specific T cell immunity in cases of COVID-19 and SARS, and uninfected controls. Nature. 584(7821):457-462. https://doi.org/10.1038/ s41586-020-2550-z

131. Dörries R, Watanabe R, Wege H, ter Meulen V (1987) Analysis of the intrathecal humoral immune response in Brown Norway $(\mathrm{BN})$ rats, infected with the murine coronavirus JHM. J Neuroimmunol 14(3):305-316. https://doi.org/10.1016/0165-5728(87)90017-8

132. Yeh EA, Collins A, Cohen ME, Duffner PK, Faden H (2004) Detection of coronavirus in the central nervous system of a child with acute disseminated encephalomyelitis. Pediatrics 113(1 Pt 1): e73-e76. https://doi.org/10.1542/peds.113.1.e73

133. Asadi-Pooya AA, Yaghoubi E, Nikseresht A, Moghadami M, Honarvar B (2011) The neurological manifestations of H1N1 influenza infection; diagnostic challenges and recommendations. Iran J Med Sci 36(1):36-39

134. Yildizdaş D, Kendirli T, Arslanköylü AE, Horoz OO, Incecik F, Ince E, Ciftçi E (2011) Neurological complications of pandemic influenza (H1N1) in children. Eur J Pediatr 170(6):779-788. https://doi.org/10.1007/s00431-010-1352-y

135. Gust J, Hay KA, Hanafi LA, Li D, Myerson D, Gonzalez-Cuyar LF, Yeung C, Liles WC et al (2017) Endothelial activation and blood-brain barrier disruption in neurotoxicity after adoptive immunotherapy with CD19 CAR-T cells. Cancer Discov 7(12): 1404-1419. https://doi.org/10.1158/2159-8290.cd-17-0698

136. Ng Kee Kwong KC, Mehta PR, Shukla G, Mehta AR (2020) COVID-19, SARS and MERS: A neurological perspective. J
Clin Neurosci 77:13-16. https://doi.org/10.1016/j.jocn.2020.04. 124

137. Fouda AY, Fagan SC, Ergul A (2019) Brain vasculature and cognition. Arterioscler Thromb Vasc Biol 39(4):593-602. https://doi. org/10.1161/ATVBAHA.118.311906

138. Carter CJ (2017) Genetic, transcriptome, proteomic, and epidemiological evidence for blood-brain barrier disruption and Polymicrobial brain invasion as determinant factors in Alzheimer's disease. J Alzheimers Dis Rep 1(1):125-157. https://doi.org/10.3233/ADR-170017

139. Bell RD, Zlokovic BV (2009) Neurovascular mechanisms and blood-brain barrier disorder in Alzheimer's disease. Acta Neuropathol 118(1):103-113. https://doi.org/10.1007/s00401009-0522-3

140. Ueno M, Chiba Y, Matsumoto K, Murakami R, Fujihara R, Kawauchi M, Miyanaka H, Nakagawa T (2016) Blood-brain barrier damage in vascular dementia. Neuropathology 36(2):115124. https://doi.org/10.1111/neup.12262

141. Kurtzke JF (1993) Epidemiologic evidence for multiple sclerosis as an infection. Clin Microbiol Rev 6(4):382-427. https://doi.org/ 10.1128/cmr.6.4.382

142. Varatharaj A, Galea I (2017) The blood-brain barrier in systemic inflammation. Brain Behav Immun 60:1-12. https://doi.org/10. 1016/j.bbi.2016.03.010

143. Holmes C, Cunningham C, Zotova E, Woolford J, Dean C, Kerr S, Culliford D, Perry VH (2009) Systemic inflammation and disease progression in Alzheimer disease. Neurology 73(10):768-774. https://doi.org/10.1212/WNL.0b013e3181b6bb95

144. Barnes LL, Capuano AW, Aiello AE, Turner AD, Yolken RH, Torrey EF, Bennett DA (2015) Cytomegalovirus infection and risk of Alzheimer disease in older black and white individuals. J Infect Dis 211(2):230-237. https://doi.org/10.1093/infdis/jiu437

145. Jaeger LB, Dohgu S, Sultana R, Lynch JL, Owen JB, Erickson MA, Shah GN, Price TO et al (2009) Lipopolysaccharide alters the blood-brain barrier transport of amyloid beta protein: a mechanism for inflammation in the progression of Alzheimer's disease. Brain Behav Immun 23(4):507-517. https://doi.org/10.1016/j.bbi.2009. 01.017

146. Weintraub MK, Kranjac D, Eimerbrink MJ, Pearson SJ, Vinson BT, Patel J, Summers WM, Parnell TB et al (2014) Peripheral administration of poly I:C leads to increased hippocampal amyloid-beta and cognitive deficits in a non-transgenic mouse. Behav Brain Res 266:183-187. https://doi.org/10.1016/j.bbr. 2014.03.009

147. Bourgade K, Le Page A, Bocti C, Witkowski JM, Dupuis G, Frost EH, Fülöp T (2016) Protective effect of amyloid- $\beta$ peptides against herpes simplex Virus-1 infection in a neuronal cell culture model. J Alzheimers Dis 50(4):1227-1241. https://doi.org/10. 3233/jad-150652

148. Brown EE, Kumar S, Rajji TK, Pollock BG, Mulsant BH (2020) Anticipating and mitigating the impact of the COVID-19 pandemic on Alzheimer's disease and related dementias. Am J Geriatr Psychiatry 28(7):712-721. https://doi.org/10.1016/j.jagp.2020. 04.010

149. Mackall CL, Gress RE (1997) Thymic aging and T-cell regeneration. Immunol Rev 160:91-102. https://doi.org/10.1111/j.1600065x.1997.tb01030.x

150. McManus RM, Heneka MT (2017) Role of neuroinflammation in neurodegeneration: New insights. Alzheimers Res Ther 9(1):14. https://doi.org/10.1186/s13195-017-0241-2

151. Naylor K, Li G, Vallejo AN, Lee WW, Koetz K, Bryl E, Witkowski J, Fulbright J et al (2005) The influence of age on T cell generation and TCR diversity. J Immunol 174(11):74467452. https://doi.org/10.4049/jimmunol.174.11.7446 
152. Raffel J, Wakerley B, Nicholas R (2016) Multiple sclerosis. Medicine 44(9):537-541. https://doi.org/10.1016/j.mpmed.2016. 06.005

153. Cusick MF, Libbey JE, Fujinami RS (2013) Multiple sclerosis: autoimmunity and viruses. Curr Opin Rheumatol 25(4):496-501. https://doi.org/10.1097/bor.0b013e328362004d

154. Owens GP, Gilden D, Burgoon MP, Yu X, Bennett JL (2011) Viruses and multiple sclerosis. Neuroscientist 17(6):659-676. https://doi.org/10.1177/1073858411386615

155. Li CK-F, Wu H, Yan H, Ma S, Wang L, Zhang M, Tang X, Temperton NJ et al (2008) T cell responses to whole SARS coronavirus in humans. J Immunol 181(8):5490-5500. https://doi.org/ 10.4049/jimmunol.181.8.5490

156. Sonar SA, Shaikh S, Joshi N, Atre AN, Lal G (2017) IFN- $\gamma$ promotes transendothelial migration of $\mathrm{CD} 4+\mathrm{T}$ cells across the blood-brain barrier. Immunol Cell Biol 95(9):843-853. https:// doi.org/10.1038/icb.2017.56

157. Fabis MJ, Scott GS, Kean RB, Koprowski H, Hooper DC (2007) Loss of blood-brain barrier integrity in the spinal cord is common to experimental allergic encephalomyelitis in knockout mouse models. Proc Natl Acad Sci 104(13):5656-5661. https://doi.org/ 10.1073/pnas.0701252104
158. Cramer SP, Larsson HB (2014) Accurate determination of bloodbrain barrier permeability using dynamic contrast-enhanced T1weighted MRI: a simulation and in vivo study on healthy subjects and multiple sclerosis patients. J Cereb Blood Flow Metab 34(10): 1655-1665. https://doi.org/10.1038/jcbfm.2014.126

159. Alvarez JI, Saint-Laurent O, Godschalk A, Terouz S, Briels C, Larouche S, Bourbonnière L, Larochelle $\mathrm{C}$ et al (2015) Focal disturbances in the blood-brain barrier are associated with formation of neuroinflammatory lesions. Neurobiol Dis 74:14-24. https://doi.org/10.1016/j.nbd.2014.09.016

\section{Related links}

International Committee on Taxonomy of Viruses (https://talk.ictvonline. org/)

World Health Organization, WHO Coronavirus Disease (COVID-19) (https://covid19.who.int/)

Publisher's Note Springer Nature remains neutral with regard to jurisdictional claims in published maps and institutional affiliations. 